DOI: $10.52950 / E S .2021 .10 .2 .003$

\title{
FINANCIAL UNAVAILABILITY OF HOUSING IN THE CZECH REPUBLIC AND RECOMMENDATIONS FOR ITS SOLUTION
}

\section{EDUARD HROMADA, KLARA CERMAKOVA}

\begin{abstract}
:
The paper deals with the issue of unavailability housing in the Czech Republic, which affects an increasing number of people. As a result of the covid-19 pandemic, there has been a significant increase in property prices and widening the price to income gap, which mainly affects young people. This paper describes the basic causes of this undesirable phenomenon in society and provides recommendations that should be quickly adopted by the state and municipalities to improve the situation as we see a risk of an increase in social tension in society and a deterioration in the availability of employment for low-income professions.
\end{abstract}

\section{Keywords:}

Housing, financial unavailability of housing, mortgages, real estate prices, employment, regional disparities.

JEL Classification: $018, \mathrm{R} 21, \mathrm{R} 31$

\section{Authors:}

EDUARD HROMADA, Czech Technical University in Prague, Faculty of Civil Engineering, Czech Republic, Email: eduard.hromada@fsv.cvut.cz KLARA CERMAKOVA, Prague University of Economics and Business, Czech Republic, Email: klara.cermakova@vse.cz

\section{Citation:}

EDUARD HROMADA, KLARA CERMAKOVA (2021). FINANCIAL UNAVAILABILITY OF HOUSING IN THE CZECH REPUBLIC AND RECOMMENDATIONS FOR ITS SOLUTION. International Journal of Economic Sciences, Vol. X(2), pp. 47-58., 10.52950/ES.2021.10.2.003 


\section{Introduction}

In recent years, there has been a significant increase in the prices of all types of real estate in the Czech Republic. From this point of view the Covid economic downturn is very different from all recent financial crises impact on property market (Cermakova 2019). This situation is caused by many factors. These are, for example, savers' fears of a significant rise in inflation (a situation opposite to the one following the 2008 crisis - as revealed by Cecrdlova, 2020), when real estate replaces standard financial products, failure to address pension reform, investors' concerns about the sharp increase in interest rates on mortgage loans, slow approval processes for buildings, lack of building land and a sharp increase in the prices of construction work and building materials (measured by costs of construction projects proposed by Heralova, 2017). The gap between household income and real estate prices is constantly widening, especially in big cities. The current situation is the worst in the history of the Czech Republic.

In the Czech Republic, unlike in Western Europe, owner-occupied housing is considered a strong social norm and a criterion for success. Many people are beginning to see housing as a form of investment, not as a means of securing their own housing. In recent years, institutional investors (real estate funds, pension funds, etc.) are buying large numbers of flats and properties as an instrument of diversification (Andelinovic 2020). Such a business strategy exacerbates the growing problem. In addition, construction companies and developers have now set up their business model so that they plan to keep part of the flats in their own portfolio from their own production and rent them out separately. This reduces the number of flats available to ordinary citizens. And the rule is that what is rare is expensive.

The worst situation then occurs in the cities of Prague and Brno. In Prague, it would be necessary to build between 10 and 15 thousand flats a year to meet demand. However, only between three and six thousand flats a year have been built in recent years. This increases the differential between supply and demand in the market every year. This difference is already so high that it is practically impossible to compensate in the horizon of, for example, 5 years, even under the assumption of massive housing construction.

The financial unavailability of housing thus affects more and more people. This problem affects young people the most. Young people want to start families and at the same time be close to their job and have quality services available in the locality (health services, school facilities, shops, etc.). Young people are forced to make compromises by increasingly living in unsuitable locations far from their jobs bearing high costs of commuting. Affordable housing has been identified as one of the primary factors of reconciliation of work and family life (Jasova 2019) and sustainable sectoral structure in regional performance (as documented by Volek 2019).

The unavailability of housing thus leads young people to postpone starting a family until they have a stable background. Also family size tends to be smaller under uncertainty about own housing, higher age of parents or excessive financial burden of housing. Due to the unavailability of 
housing, the number of parents with only one child will increase. This situation is not in the interest of the state and society.

The state should therefore take many steps in this area as a matter of urgency to mitigate this negative trend. The authors are convinced that in this area it is not possible to rely only on the private sector, because the interest of the private sector is primarily the generation of profit and not work in the public interest. This article provides some recommendations on how to address this issue.

\section{Recommendations to reduce the financial unavailability of housing}

\subsection{Development of public - private cooperation in the field of construction and operation of housing}

Many developers are currently just trying to make the most of what is possible in terms of profit generation. They are not interested in the wider project environment and focus only on their building land. However, each new construction affects the immediate surroundings, and it is necessary to participate in the co-financing of the induced investments (construction of schools, wastewater treatment plant, sidewalks, public lighting, parking and much more).

Active cooperation between the public and private sectors could help to solve the problem. This cooperation can take various forms. For example, a municipality may invest in a building plot and the private sector will provide construction. Many municipalities have their own plots of land that could be used for residential construction, and the private sector can offer know-how associated with housing construction.

PPP projects (Public Private Partnerships) can be a great opportunity. The Ministry of Regional Development is preparing the first model PPP project for the construction of affordable rental housing. The pilot plan envisages the construction of 1,380 flats for defined target groups for approximately CZK 3 billion [MMR].

Public private partnerships are successfully used abroad in the area of affordable housing. The United Kingdom has the most experience in this area. The advantage of this form of cooperation is that the state would not have to go into debt. The consortium would ensure the construction and operation of affordable housing. The state would pay fees for the availability of affordable housing. The apartments would be state-owned for the duration of the concession agreement.

Using the PPP form, the state can start creating an apartment portfolio for needy citizens (needed professions - medical staff, teachers, police officers, firefighters, single people, seniors, disabled people etc.). The state and municipalities need to ensure that the necessary professions can live in large cities with expensive housing.

\subsubsection{The city of Vienna - a model of a functioning city in terms of housing}


Vienna is a very good example of public-private cooperation. The city management has been comprehensively solving the problem of housing construction and support for affordable housing for approximately 100 years. The city thus manages to keep the costs associated with housing at an acceptable level. The city is always ranked at the top of the world in terms of the quality of living.

The city of Vienna has not been hit hard by the covid-19 pandemic. It is common for ordinary citizens to live in tourist-exposed neighbourhoods, and regular services and shops are available here. The whole system of housing policy in Vienna is based on two pillars: urban and cooperative flats and new construction. [ALA]

About 78 percent of the population lives in rented flats in Vienna. 40 percent of all apartments are structured directly as affordable housing. The city government is aiming that people should not spend more than twenty to twenty-five percent of their family's income on housing. 8.7 flats per 1,000 inhabitants are permitted in Vienna. Previously, it was not de facto possible to conclude a lease other than a contract of indefinite duration. Today, it is possible to rent apartments on the market for a definite period of three years.

For comparison, the city of Prague sold almost its entire housing stock. Only 3.4 flats per 1,000 inhabitants were allowed in Prague. New municipal flats in Prague have only been developed to a very limited extent in recent years. Lease agreements are concluded for a maximum period of one year, which leaves tenants in constant uncertainty as to whether their lease will be extended for another year and at what rental price. The ownership of rental flats in Prague is very fragmented, which causes confusing and unprofessionalism of the rental market.

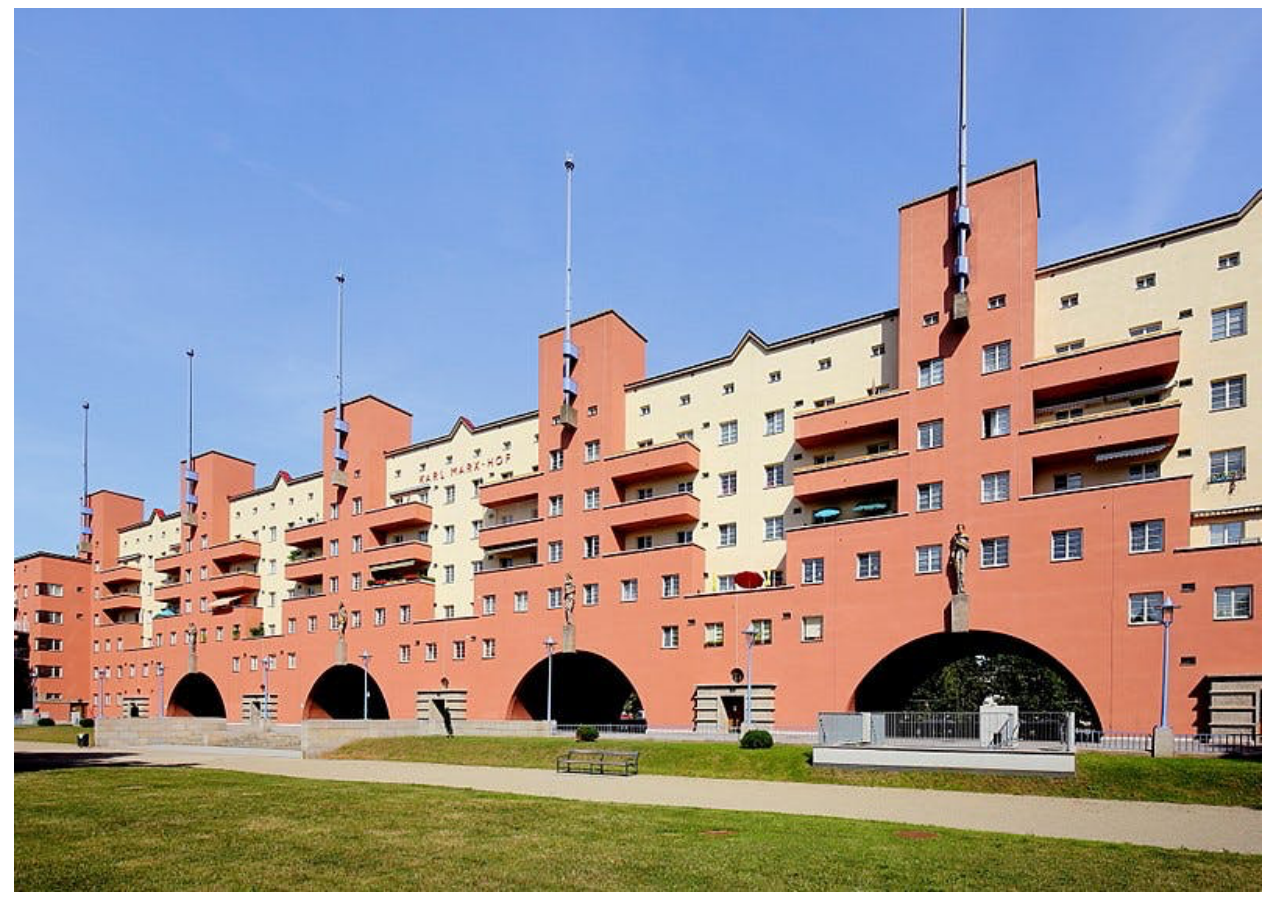

Figure 1 Karl-Marx-Hof apartment complex (1927-1930) 
Source: Karl Marx in Vienna, https://secretvienna.org/karl-marx-in-viennal, 2021.

\subsection{Acceleration of permitting processes, reduction of bureaucracy}

At present, according to the World Bank's ranking, the Czech Republic is in an unflattering 184th place in terms of building permits speed. Due to complicated permitting processes, construction housing projects are prepared for a disproportionately long time. Thus, construction companies and developers cannot react flexibly to the current state of market demand. Complex permitting processes also make construction more expensive. The result is slow and expensive construction.

This year, the Chamber of Deputies approved a new building law, which is intended to significantly speed up and simplify construction process. According to this law, all building authorities have to go under the state and will fall under the Supreme Building Authority. The aim is also that the citizen does not have to go to office thanks to digitalization. At present, however, it seems that the new government will repeal this building law. According to critics, the new building law should have gone to the hands of developers.

\subsection{Reduction of the VAT rate on residential buildings}

According to current legislation, there is applied the first reduced VAT rate of $15 \%$ to buildings. In order to apply the first reduced rate, two conditions must be met: it is work on the completed construction and at the same time the building meets the definition of a residential building or a social housing building.

Table 1 Types of VAT rates in the Czech Republic

\begin{tabular}{|l|l|l|}
\hline VAT rates & Value & Examples of use \\
\hline Basic VAT rate & $21 \%$ & $\begin{array}{l}\text { It applies to all goods and all services that are not } \\
\text { included in the VAT Act for a reduced rate. }\end{array}$ \\
\hline The first reduced VAT rate & $15 \%$ & $\begin{array}{l}\text { It applies to the sale of goods listed in Annex } 3 \text { of the } \\
\text { VAT Act, such as the sale of food and non-alcoholic } \\
\text { beverages, plants and seeds, and animal feed. It also } \\
\text { applies to the services listed in Annex 2, such as } \\
\text { funeral services. Construction or assembly work carried } \\
\text { out on a completed building, in the case of a residential } \\
\text { building or a social housing building. }\end{array}$ \\
\hline The second reduced VAT rate & $10 \%$ & It applies to the sale of goods listed in Annex 3a) of the \\
\hline
\end{tabular}




\begin{tabular}{|l|l|}
\hline & $\begin{array}{l}\text { VAT Act, such as the sale of infant formulas and follow- } \\
\text { on formulas, the sale of medicines or the sale of } \\
\text { drinking water. It also applies to services listed in Annex } \\
\text { No. 2a) to the VAT Act. These include accommodation } \\
\text { and catering services, hairdressing and barber services, } \\
\text { admission to cinemas and theaters. }\end{array}$ \\
\hline
\end{tabular}

Source: Ministry of Finance of the Czech Republic, https://www.mfcr.cz/, 2021.

Residential buildings are then defined as follows:

- construction of an apartment building,

- construction of a family house,

- construction which is used for the construction of an apartment building or the construction of a family house and is established on land that forms a functional unit with this construction of an apartment building or family house,

- living space,

- a room used together with the living space referring to the previous point, located in the same building firmly connected to the ground. [DPH]

Social housing buildings are understood as:

- construction of an apartment building in which there is no living space with a floor area exceeding $120 \mathrm{~m}^{2}$,

- construction of a family house with a floor area not exceeding $350 \mathrm{~m}^{2}$,

- living space for social housing,

- accommodation facilities for members of security forces,

- school facilities for institutional education,

- boarding schools,

- children's homes for children up to three years of age,

- facilities for children requiring immediate assistance and facilities for foster care, 
- special hospice-type inpatient facilities,

- war veterans' care homes,

- other buildings. [DPH]

In the opinion of the authors, the above characteristics are well defined and there is no need to extend them to other groups of real estate. However, the applied VAT rate of $15 \%$ is very high and makes construction significantly more expensive. This rate was set at a time when real estate was not as expensive as at present. At present, the state collects much more funds from this tax than originally expected. This is also one of the reasons why this rate should be reduced.

In the event of a reduction in the VAT rate, for example in the range of 5 to 10 percent, it would certainly be reflected in the final real estate prices. However, it can be assumed that part of the savings would be retained by construction companies and developers in order to increase their profits. The aim of the recommendation is to support the supply side as much as possible in order to motivate them to build as much as possible. A larger supply of apartments for sale on the market will reduce the pressure on the demand side which will have an impact on property prices.

\subsection{Development of transport infrastructure}

According to the findings of the Czech Statistical Office, almost 140,000 people from the Central Bohemian Region commute to Prague for work, school or services. Over the last 15 years, the number of commuters has increased by 47 percent. The commute to Prague takes place mostly from the districts of Prague-West and Prague-East. Lukavec (2017) reveals how property price chenges with increased commuting time. The Central Bohemian Region thus partially fulfills the function of a dormitory for workers from Prague. A similar situation as in Prague, although on a smaller scale, occurred in the vicinity of Brno, Pilsen and Ostrava, whose background is also expanding. 


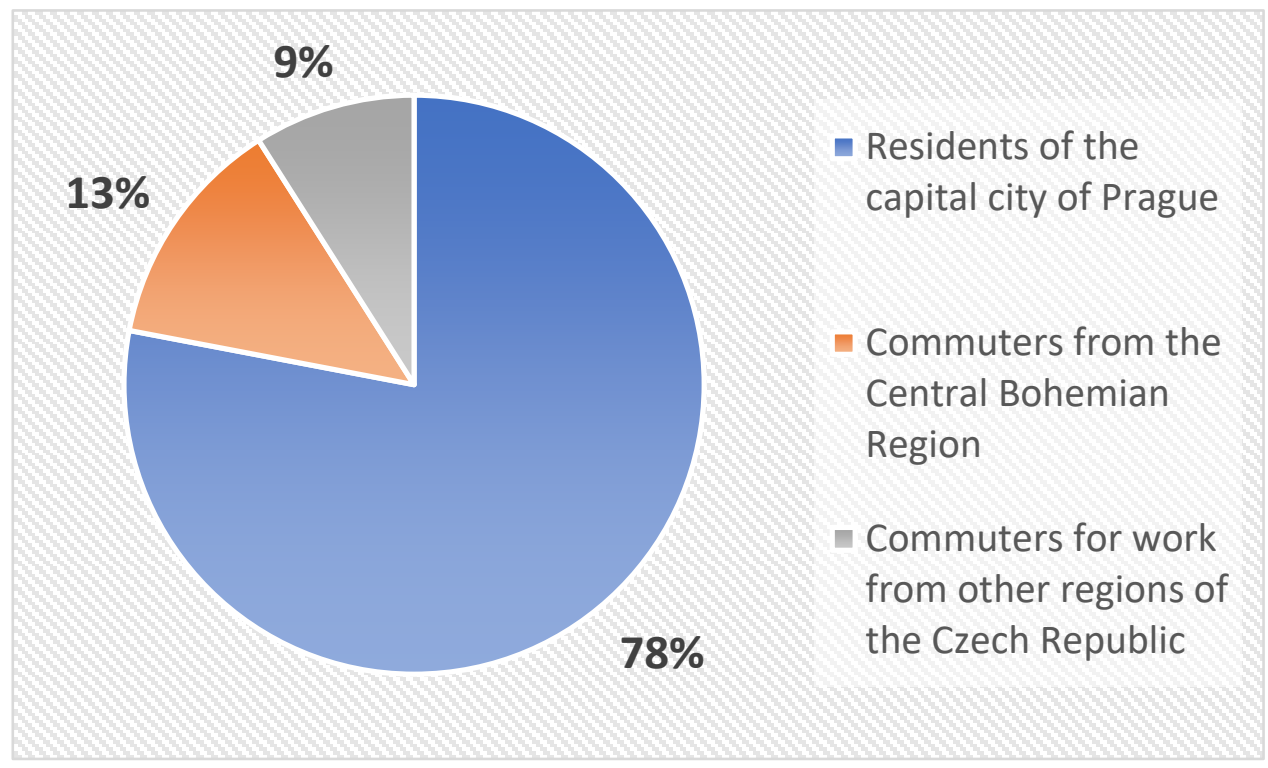

\section{Figure 1 Occupancy of jobs in the capital city of Prague according to the source of commuting}

Source: Czech Statistical Office https://www.czso.cz/csu/czso/13-1127-04-sldb 2001-

4 dojizdka za praci, 2021.

The capital city of Prague represents a center of job opportunities, a center of social and cultural life, a high concentration of school and medical facilities, state authorities and other services. If there is a quality transport infrastructure, it would be possible for people from more distant regions to commute to Prague in a reasonable time and quality of travel. This would reduce the pressure on the need to live directly in Prague and in custody would reduce the demand for housing in Prague and thus the price level. The state should therefore focus mainly on the development of railway transport infrastructure. However, solving this problem is only possible in the long term.

\subsection{Support for the first owner-occupied housing}

There are many investors on the real estate market who buy apartments for the purpose of their further lease. Real estate has become a substitute for standard savings products. This reduces the opportunities for young families to acquire owner-occupied housing. The state should therefore favor this target group.

However, the Czech National Bank tightened the limits for providing mortgages with effect from April 2022. The ratio of the amount of the mortgage loan to the value of the mortgaged property (LTV) decreased to 80 percent from the previous 90 percent. At the same time, it renewed further income limits for the provision of mortgages. 
The limit of the DTI indicator (the applicant's total debt expressed in multiples of his net annual income) will be 8.5 (9.5 for applicants under 36 years of age). The limit of the DSTI indicator (ratio between the total amount of monthly loan repayments of the loan applicant and his net monthly income) will be $45 \%$ (50\% for applicants under 36 years of age). The Czech National Bank reduces the upper limit of the LTV indicator (Ioan-to-value ratio) to $80 \%$ (90\% for applicants under the age of 36). [CNB]

The management of the Czech National Bank believes that the set limits will limit only a small part of mortgage loans, namely those with potentially the riskiest parameters. Potentially, this should affect a maximum of about ten percent of mortgages.

The authors believe that in this area, on the contrary, the state should take over the guarantee of the risk of non-payment of mortgage loans by young families. On the contrary, the set measures will lead to a reduction in the availability of mortgages for young people, as the above measures are due to apply from April 2002.

\subsection{Modification of parameters of the State Investment Promotion Fund}

The State Investment Promotion Fund (SFPI) provides loans and subsidies for housing, the regeneration of public spaces and the construction of rental housing. However, the parameters of this fund are unusable for Prague, while the biggest housing crisis is in Prague. There are two basic problems. The subsidy of CZK 35,000 per square meter is low in Prague conditions. The second problem is the condition that in the built apartments people have to pay rent only CZK 64,36 per square meter per month [SFPI]. This is an unrealistically low amount for Prague. It is necessary that these conditions be adjusted separately for Prague. At the same time, the budget of the State Investment Promotion Fund should increase.

\subsection{Shortening the depreciation period for the construction of rental housing}

Shortening the depreciation period for the construction of rental housing would lead to greater motivation for investors to build rental apartments. Investors can thus improve their current cash flow and achieve lower tax obligations. At the same time, low tax liability will lead to lower advances for future tax periods.

The amendment to the Income Tax Act [INC] brought the possibility of using extraordinary depreciation of tangible assets. However, extraordinary depreciation can be applied to tangible assets, which are classified only in depreciation groups 1 and 2 . However, real estate belongs to depreciation groups 5 and 6.

\subsection{Shortening the deadline for applying income tax when selling real estate}


The sale of real estate is exempt from income tax if at least five years elapse between its acquisition and sale. This deadline applies to the sale of all real estate acquired before 31 December 2020. In the case of real estate acquired from 1 January 2021, the new deadline is ten years. Thus, the ownership rule of 5 or 10 years (so-called "time test") applies to the tax exemption, depending on when the house or apartment was acquired. [TEST]

The Ministry of Finance of the Czech Republic expects that this measure increases the availability of housing in the long run, encourage a cooled real estate market and reduce the space for speculators. However, the authors are convinced that extending the time test is counterproductive and will reduce the number of real estate sales. Property owners would rather keep property unused or rent it at a disadvantage than sell it and have to pay income tax. This restriction will also support the development of the gray economy. The level of real estate speculation is widespread especially in poor regions of the Czech Republic, where it is possible to draw various social benefits associated with housing. However, this problem affects Prague to a limited extent.

\section{Conclusions}

It is estimated that 30,000 new flats are currently missing in Prague. The main reasons revealed by Hromada (2021) are slow construction, a non-functional building law and a peaking demand in recent two years. During the Covid-19 pandemic, new residential construction was limited as a large share of guest construction workers left (as documented by Kaderabkova, 2020). Even if recent months brought an increase in number of iniciated construction projects, the property market data suggest that property supply still is not able to cope with the demand dynamics. We argue that, in the years to come, there is no market driven mechanism that could solve housing affordability issue without municipality/state intervention.

In recent years, only between three and six thousand flats a year have been built in Prague. For comparison, approximately 20,000 new flats are created annually in Warsaw. All countries neighboring the Czech Republic are implementing significantly more massive residential construction than in the Czech Republic. In addition, neighboring countries are trying to accelerate residential housing due to global pressure. Also the Prague municipality is facing the challenge to start building affordable housing, otherwise housing in Prague will become highly selective and some lower-income residents will be forced to leave the city due to the very high housing costs. As a result, Prague would lose the potential for its further development.

\section{Acknowledgements}

This research was founded by TA ČR Beta 2, TITASCU 920 and IGS F5/2/2020. 


\section{References}

ANĐELINOVIĆ, M., PAVKOVIĆ, A., VALENTIĆ, L. (2020). Equity Fund Performance and Sector Diversification. International Journal of Economic Sciences, Vol. IX(1), pp. 25-43. , DOI:

10.52950/ES.2020.9.1.002

Čermáková, K., Jašová, E.: Specification of recent financial crisis in the Czech Republic during 2008-2016 in comparison with previous financial crises, in particular during 1990's. 13TH INTERNATIONAL DAYS OF STATISTICS AND ECONOMICS, 2019, DOI: 10.18267/pr.2019.Ios.186.26

Čečrdlová, A. (2020). Symmetric Behaviour to Fulfil the Main Objective as the Basis for the Credibility of Central Banks Behaviour on the Example of CNB . International Journal of Economic Sciences, Vol. IX(1), pp. 68-82. , DOI: 10.52950/ES.2020.9.1.004

[MMR] Klára Dostálová: Připravujeme první PPP projekt výstavby nájemního bydlení [online]. Prague: The Ministry of Regional Development, 2021 [cit. 2021-12-11]. Available from:

https://www.mmr.cz/cs/ostatni/web/novinky/klara-dostalova-pripravujeme-prvni-ppp-projekt-vys

[ALA] Vídeň: systém bydlení, který obdivuje celý svět, berou místní jako něco úplně normálního [online]. Prague: A2larm.cz, 2021 [cit. 2021-12-11]. Available from: https://a2larm.cz/2020/09/viden-systembydleni-ktery-obdivuje-cely-svet-berou-mistni-jako-neco-uplne-normalniho/

[DPH] Act of 235 April 2004 No. 235/2004 Coll., the Value Added Tax Act, as amended.

[CNB] ČNB nově nastaví limity ukazatelů LTV, DTI a DSTI u hypotečních úvěrů, zvýší i proticyklickou kapitálovou rezervu na 2 \% [online]. Prague: the Czech National Bank, 2021 [cit. 2021-12-15]. Available from: https://www.cnb.cz/cs/cnb-news/tiskove-zpravy/CNB-nove-nastavi-limity-ukazateluLTV-DTI-a-DSTI-u-hypotecnich-uveru-zvysi-i-proticyklickou-kapitalovou-rezervu-na-2-I

HROMADA, E., KRULICKY, T. Investing in Real Estate in the Czech Republic and Analyzing the Dependence of Profitability and Technical and Socio-Economic Factors. Sustainability. 2021; 13(18):10273. https://doi.org/10.3390/su131810273

Jašová, E., \& Kadeřábková, B. (2019). Analysis of Effects of Reconciliation of Family and Work Life of Women Through the Prism of Non-accelerating Inflation Rate of Unemployment in the Czech Republic. Politická ekonomie, 67(3), 316-332. doi: 10.18267/j.polek.1216

Kadeřábková, B., Jašová, E. 2020: Comparation of the economic cycle on labour market in the construction industry and in the national economy of the Czechia. Civil Engineering Journal Stavebni obzor,3/2020, DOI 10.14311/CEJ.2020.03.0024

Lukavec, M., Kaderabkova, B. How much does a minute of commuting time cost? An examination of property prices in relation to distance to the city center in Prague, Czech republic, Civil Engineering Journal - Stavebni obzor (2017), DOI: 10.14311/CEJ.2017.04.0044

[SFPI] Výstavba pro obce [online]. Prague: Státní fond podpory investic, 2021 [cit. 2021-12-16]. Available from: https://sfpi.cz/vystavba-pro-obce/ 
Schneiderova Heralova, R. Life Cycle Costing as an Important Contribution to Feasibility Study in Construction Projects, Procedia Engineering, Volume 196, 2017, Pages 565-570, https://doi.org/10.1016/i.proeng.2017.08.031

[INC] Act No. 586/1992 Coll., The Income Tax Act, as amended.

[TEST] Přehled nejdůležitějších změn v gesci Ministerstva financí pro rok 2021 [online]. Prague: Ministry of Finance of the Czech Republic, 2021 [cit. 2021-12-16]. Available from: https://www.mfcr.cz/cs/aktualne/tiskove-zpravy/2020/prehled-nejdulezitejsich-zmen-v-gesci-mi$\underline{40144}$

Volek, T., Novotna, M. The role of sectoral structure in the regional performance Conference paper International Days of Statistics and Economics 2019, DOI:10.18267/pr.2019.Ios.186.163 